\title{
THE STRUCTURE OF THE BUREAU OF INDIAN AFFAIRS
}

\author{
STEVE NICKESON*
}

The Bureau of Indian Affairs has always had a militant disinclination toward change. It is like Mother Nature: it can be probed, occupied, undermined, or incinerated, but its essence always seems to remain immutable, its form determined more by the composite debris of passing careers than by directed action. Any efforts to encourage basic change become the feckless hobbies of frustrated men.

Like most bureaucracies, the BIA frequently gives a superficial appearance of change while moving to preserve its existing structure. An excellent illustration of this process was provided early in this decade, when the BIA agreed that the federally recognized tribes should have 20 per cent of the influence over the Bureau's budget formulating process. Tribal officials were given an approximation of how much money would be available on their reservations, and they drafted budgets that reflected local priorities from among the Bureau's five program areas: Education, Indian Services, Reservation Resource Development, Trust Responsibilities and Services, and Administration. The tribes' imput was first blended with the federal government's 80 per cent control to create the FY 1974 budget, which was not questioned. But the next year the tribal representatives compared their own priorities with the amounts the BIA had budgeted for each program area and it was clear that the two did not mesh.

The evidence was on two graphs. The first graph showed program sizes and projected growth rates of the Bureau's approved FY 1975 budget. The second one did the same for a set of figures that a computer analysis indicated would have been the 1975 budget had the Bureau honestly given the tribes 20 per cent control.

On the first graph Education was the largest, fastest growing Bureau expenditure. Indian Services was second in size and rate of growth. Reservation Resource Development was small and growing slowly. Trust Responsibilities and Services was one-tenth the size of Education and was not growing at all. Management (fixed administrative costs) was of moderate size and growth.

But on the second graph, the one that reflected 20 per cent tribal input, Education was tapering off into a slow-growing, low priority program. Indian

\footnotetext{
* Staff member, National Indian Youth Council, Albuquerque, New Mexico; former Senior Editor of the Race Relations Reporter.
} 
Services once again followed Education's rate, but was slightly larger. Reservation Resource Development was taking a drastic jump upward to overshadow the first two areas. Trust Responsibilities and Services was climbing vertically from the bottom to become the largest Bureau expenditure. And Management was continuing its moderate way.

In short, the Bureau had thrown the tribal input away because it pointed in the direction of unrestricted trust protection and economic self-sufficiency instead of supporting the Bureau's policies of off-reservation education and the maintenance of reservations as welfare states.

When the findings were displayed and explained during a national conference, ${ }^{1}$ the reaction was a subdued acknowledgement that business was usual at the Bureau. Chalk up another lie, another reason for loving to hate, additional proof for whatever theory one has for making reason out of what appears as federal madness. But none of these theories-the BIA as a racist conspiracy, or a colonial office, or a black hole in space-explains the budget sharing lie as well as the simple notion that the tribes had attacked the Bureau's entire organizational and policy structure. For the Bureau to have turned over to the tribes control of a significant proportion of the budget - particularly in the area of education ${ }^{2}$ - would have been to revolutionize the entrenched bureaucracy that has grown up in support of a policy aimed at bringing Native Americans in line culturally and economically with the majority population.

The budget sharing proposal is only one of a host of programs that has sought directly or indirectly to restructure the relations between the BIA and the Indians. As the central administrative agency for federal Indian policy, the BIA has an immense impact on the daily lives of reservation Indians. To understand the possible impact of new proposals one must consider two centuries of policy structure and the power of all those who have a vested interest-professionally, personally, or ideologically-in maintaining the present system. To confront change realistically, one must consider the true structure of the Bureau; one must consider policy and the power that it generates.

The Bureau of Indian Affairs has several structures. One is visible, the rest are nonetheless real. The visible one is represented in the Bureau's mercurial organization manual and flow chart. These documents are dependable for mapping the advance of paperwork and naming offices, but beyond that they can be misleading because they show little more than a thin, single dimension of an organization that does not always work according to its schematic design. It could only do so if the Bureau were a mass of managerial theory bound by inflexible rules instead of a mass of human beings bound by

1. National Conference on Tribal Policy, Washington, D.C., June 5-6, 1974.

2. The education budget for FY 1976 is $\$ 230$ million, while the budget for trust responsibilities is $\$ 21$ million. 
regulations, politics, loyalties, fears, ideals, and ambitions.

At present the flow chart shows power percolating down from the Commissioner and Deputy Commissioner through the Central Office staff and the Area Offices to the Agency Offices. The basic Central/Area/Agency structure is a generation old, and was arrived at, like many things in the Bureau, by legislation that justified and organized past practice.

Just as the aged sometimes resemble themselves in childhood, so too the Bureau's three-tiered structure resembles its early organization. At its birth in 1824 the Bureau consisted of a Commissioner linked directly to the Indian Agents in the field. For ease of administration, regional superintendents were later placed between the two. As the Bureau expanded during the Alloment period, the Indian Agent became an Agency Superintendent and the old regional superintendent network formed the basis of a new structure for administrative officers. As Indian programs proliferated at the turn of the century, separate regional systems developed for each of them. By the time Laurence Schmickebier completed his inspection of the Bureau in 1927, separate regional structures existed for health, irrigation, administration, and education, and the agency superintendents were reporting directly to the Central Office. ${ }^{3}$ This visible structure had grown helter-skelter and did not square with the fundamental bureaucratic need for efficiency and uniformity of action. It took twenty years from the publication of Schmickebier's study to harmonize the discord into the Central/Area/Agency arrangement, a structure John Collier had proposed in the 1930 s as a way of aiding the transfer of power from Washington, D.C. to the reservation. The transfer stopped, however, the instant the Area Offices realized they were not simply intermediaries, but the heads of miniature Central Offices capable of controlling communication between Central and Agency, and back again. Naturally political alliances formed along the lines of communication, and in no time the Area Offices became the frontier checkpoints for those going in or out of Indian Country.

One definition of a bureaucracy says it is "always a government of experts, of an "experienced minority." " The Bureau makes that observation a cliché, and the Bureau's most experienced minority are the Area Office Directors. They are the only personnel who have as much daily contact with the reservations as they do with the Central Offices; they know the politics, the strengths and weaknesses, and the prices of each one. They also have the cohesion, the pay grade, the line authority, the friends in Congress, and organized pressure groups to make the system conform to their expectations. They have several distinct advantages over anyone in the Central Office, not to mention their subordinates in the Agencies.

3. L. Schmickebier. Structure of the BiA (1927); see especially the appendix on locations of Bureau installations.

4. H. Arevit, Origins of Totalitarianisi 214 (1951). 
In theory most of the Bureau's power is in the Central Office because it is delegated there broadly by Congress and specifically by the Secretary of Interior; from Central it is to be delegated on down the chart. But delegated power is controlled by those who delegate it: it is visible and the actions it precipitates are constantly monitored by the Administration, Congress, the press, and the major Indian organizations. But the Area Offices are not always subject to that kind of scrutiny and the powers delegated to them can be exercised with greater impunity. The power to play favorites, to meddle in tribal politics, to obscure issues or decide matters not covered in the manual are largely invisible powers. And the less they are seen the more arbitrary and absolute they can become. They are powers the Area Officials had successfully fought to maintain for many years, and they were secure with that power when Robert Bennett left office as Commissioner of Indian Affairs in 1969. But their past struggles were minor compared to the one that began after Bennett's departure. It is a story that provides more information on the Bureau and its structure than any organizational manual, flow chart, or anatomical exploration. ${ }^{5}$

The first warning of battle came in the fall of 1969 when Louis Bruce, on assuming the duties of Commissioner, announced that his administration would be opposed to the policy of terminating the special status of Indian tribes. It is ironic that such a pronouncement would bode any disastrous consequences because termination had long since been discredited and few if any in the Bureau paid it tribute. In fact termination was not the point at all. Rather, by noting his opposition to termination, Bruce was forecasting changes in policy. And in the context of the times a policy change could only mean a loss in the Bureau's regulatory abilities and a gain in the tribes' independence. In the coming months, as Bruce's intentions became clearer, the Commissioner found himself opposed by two distinct but allied factions within the Bureau, the Old Liners and the Hard Hats.

All bureaucracies need Old Liners just as all armies need career NCO's. Old Liners are the doctrinaire lifers who can recognize more faults in a bureaucratic agency than anyone on the outside, but are loyal to it nonetheless. For better or worse, they make agencies like the BIA work by applying with annoying objectivity the dictates of the Code of Federal Regulations and the Bureau's manuals of policy guidelines. They know that, in the absence of proper contacts and political dexterity, imagination can be a liability in a civil service career. Instead they prefer to take the creativity and imagination of others and make them work, provided there are complete instructions.

5. The progress of this three-year war within the Bureau was closely covered in the dispatches of Richard La Course and Karen Ducheneaux of the American Indian Press Association, and two writers for the Race Relations Reporter, Frye Gaillard and the author. Most of the following material is derived from these sources. 
Old Liners shun idealism, except in the most general sense, because ideals tend to become tinged with politics and interfere with that repetition of daily tasks which passes for efficiency. If neither law nor bureaucratic precedent can be applied action stops because an Old Liner would rather not act than act in error. However, if policy conflicts with either their generalized ideals or their expectations Old Liners have the power to subvert that policy or to undermine the actions of their superiors. And like all loyalists, Old Liners can become confused or vengeful when those they serve do not share or respect their fidelity.

If there is a generalized ideal in the Bureau which Old Liners have promoted to the status of doctrine, it is the ideal of merging Indians into nonIndian society with a minimum of confusion and conflict. It is up to others to facilitate or impede the appropriation of Indian wealth into the non-Indian economy, and it is the Old Liners' perceived duty not to oppose these powers, but to find ways to make them compatible with their own conception of gradual merger. In recent years, with the Indians' emphasis on self-determination, control of resources, and tribal sovereignty, Old Liners have found it increasingly difficult to practice their ideal or maintain a sense of professional integrity based on this two-centuries-old doctrine. It is, therefore, little wonder that Old Liners became irritable in the face of Bruce's emphasis on non-assimilation, self-determination, and tribal sovereignty.

But Bureau personnel is not limited to Old Liners. The Bureau has produced or acquried employees who have combined imagination and political skill with an ability to conform or make nonconformity secretive or palatable. To make this combination work, to parlay it into power, requires time and the ability to survive. Those who survive in the Bureau are those who have inherited the doctrinal ideal of a bureaucrat's life. In other words, conservatives survive safe in the knowledge that they are the experts who are more capable of governing the people they serve than the people themselves. When this form of institutional arrogance is added to political acumen a Hard Hat is created. ${ }^{6}$

6. Such multi-faceted combinations are rare, but they exist and those who embody them are truly powerful. History had no better prototype of the Hard Hat than Lord Cromer, British Consul General in Egypt from 1883 to 1907. In his final summation, an essay entitled "The Government of Subject Races," published one year before his death, he stated:

Cromer started by recognizing that "personal influence" without a legal or written political treaty could be enough for "sufficiently effective supervision over public affairs" in foreign countries. This kind of informal influence was preferable to a well-defined policy because it could be altered at a moments notice and did not necessarily involve the home government in case of difficulties. It required a highly trained, highly reliable staff whose loyalty and patriotism were not connected with personal ambition or vanity and who would even be required to renounce the human aspiration of having their name connected with their achievements. Their greatest passion would have to be for secrecy... for a role behind the scenes; their greatest contempt would be directed at publicity and people who love it. 
Like the Old Liners, Hard Hats can be highly skilled technicians servicing the policy structure of the Bureau. But Hard Hats will always retain an undercurrent of personal amibiton, while Old Liners will always be subordinates no matter how high in the Bureau they advance. It is that personal ambition and the skills of promoting it that set the Hard Hats apart and enable them to create another dimension to the Bureau's structure, one grounded in personal power.

A Hard Hat can begin a career at the Agency level, but cannot thrive there since the potential for power is limited and the scrutiny of a tribe can be scathing. By the same token a Hard Hat cannot be master of the Bureau, because the top level of Central is too exposed to the examination of the Administration, Congress, the press, and the major Indian organizations. Although they can survive and thrive in those Central Office positions ranked just below Deputy Commissioner, they fare best in the top levels of various field operations. That is where the Hard Hats have their jealously-guarded power, and from where a handful of them can be as successful as a Bureau full of Old Liners in frustrating any policy or colleague that challenges them. Louis Bruce and his administration did exactly that.

Eight months after Bruce became Commissioner, President Nixon delivered his "self-determination without termination" policy to Congress, ${ }^{7}$ and Bruce felt the responsibility to implement it. He assumed he had the support of the Administration, especially Secretary of Interior Walter Hickel, who began 1970 with an "executive realignment" in the Bureau's Central Office. This reshuffling upgraded Bruce's authority by abolishing the posts of Deputy Commissioner and six Assistant Commissioners and replacing them with the lower ranking positions of two Associate Commissioners and five Staff Directors. Nine months later, Hickel announced the appointment of fifteen Indians to key Bureau positions. This was the New Team who, under Bruce's guidance, was to start changing policy. However, it soon became clear that even Bruce's fervor for reform was lagging behind that of several New Teamers (a group that can be called the Insurgents), who began taking over the direction and speed of Bureau renovation. None of the New Team, particularly the Insurgents, had been made by the Bureau. Their loyalities were toward Indian self-determination, and they had been educated in the minor-

Cromer himself possessed all these qualities to a very high degree; his wrath was never more strongly aroused than when he was "brought out of [his] hiding place," when "the reality which before was only known to a few behind the scenes [became] patent to all the world." His pride was indeed to "remain more or less hidden [and] to pull the strings." In exchange, and in order to make his work possible at all, the bureaucrat has to feel safe from control-the praise as well as the blame, that is-of all public institutions, either Parliament... or the press.

H. ARENDT, supra note 4, at 213.

7 . Nixon's Environmental Reorganization Plan, Text of Indian Message, 28 CoNG. Q. 1820 (1970). 
ity movements of the 1960s and the War on Poverty. None was old enough to have worked under the termination administrations of Commissioners Glenn Emmons or Phileo Nash, but they knew that no new policy had replaced that of termination. They also knew they were moving into a slightly derelict, caretaker Bureau that was operating from issue to issue, doing its best to prevent the worst. Reportedly, the Bureau was performing its routine task well when they arrived; it was an Old Liner's Bureau, controlled by the Area Directors, and as such it had no consolidated, structural ambition or reformist zeal. But 1969 was a time for zealots and the Bureau was an anachronism.

As the struggle for a guiding policy sharpened, all issues became political issues. Insurgents and Old Liners differed as to the means by which new policies should be implemented, with the former advocating more direct control of programs by the tribes. The Insurgents also differed from the Hard Hats, whose imagination and political acumen they shared, but whose control of the Area Offices was an obstacle to the Insurgents' own political goals. As every issue became a vehicle for political struggle each side accused the other of being secretive, power hungry, lawless, and arbitrary. In time, it became clear that Secretary Hickel was willing to back Commissioner Bruce and the Insurgents against the Hard Hats. On November 24, 1970, Bruce and Hickel announced the "Rotation Policy." 8 This policy transformed the Area Offices into "Support Service Centers," a name almost as banal as the status envisioned for them. This part of the program was designed as a policy offensive in the spirit of self-determination. But rotation affected the power structure as well with its plan to transfer Area Directors from post to post in order to break their holds on their personal constituencies. It was a program designed by the Insurgents to win the hearts and minds of the Old Liners and reservation leaders who were known to resent the independent power of the Hard Hats. The opposition itself was off guard and in retreat. But there was no time for the Insurgents to capitalize on the gain, for Hickel did not remain as Secretary of Interior for long.

In the first six weeks of Rogers Morton's administration, the new Secretary created a Management Assistance Survey Team to examine the workings of the Bureau. He also named to his personal staff Miss Wilma Victor, a conservative, politically influential charter member of the Haskell Mafia-a closeknit contingent of Indian Old Liners who had attended Haskell, a school run by the BIA, and who trace their standing in the Bureau back to the first Indian preference policies of John Collier. Her elevation from head of the education department of the Phoenix Area Office to Special Assistant to the

8. U.S. Dep't of INTerior, Proposed Chances in Structure and Policy of the Bureau of INDiax AfFalRs (1971) explained the policy and had atlached a letter of policy clarification from Commissioner Bruce to all tribes, Dec. 13, 1971. 
Secretary for Indian Affairs was an entirely gratuitous blow for the Hard Hats.

Then in May 1971 the Management Assistance Survey Team began supplying ammunition for the Old Liners when it reported that a significant gap had developed between Central and all field offices, and that the existing administrative and organizational "turmoil" had been caused by attempting to implement self-determination by decree. It added weight to the Old Liners' charges that the Insurgents were trying to make self-determination an "event" rather than an evolutionary process and were bending laws and issuing procedural orders that conflicted with both precedent and regulation. The Insurgents responded that if they were to comply with the Nixon antitermination policy when the regulations were designed to justify termination, they had to do things that had never been done before. During those first months of the Bruce administration, as journalist Frye Gaillard has written, the Insurgents did indeed institute some novel procedures: ${ }^{9}$

[F]or a while, things happened around the BIA that had never occurred before. As acting director of economic services, Leon Cook with the help of such lieutenants as William Veeder and Phillip Corke . . began an enthusiastic defense of Indian land and water rights. Browning Pipestem unearthed the legal justification for a broad range of policies, including an obscure 1946 solicitor's opinion that upheld preferential hiring and promotion of Indians within the Bureau. Ernest Stevens, as director of community services, began revamping the BIA's urban relocation program, and Alexander McNabb plunged into the task of negotiating self-determination contracts with various tribes and Indian groups.

But by the summer of 1971, the anti-Insurgent opposition, smarting under the effect of these innovations, regrouped for a counter-attack. They were assisted by a second conservative on the Secretary's staff, William Rogers, whose promotion on June 25 from Deputy Under-secretary for Public Land Management to Deputy Assistant Secretary for Indian Affairs was intended to heal the factionalism in the BIA staff. The first objective of the counter-attack was the alteration of contracting procedures.

For some time the Insurgents had been operating as if the Area Offices had in fact become Support Service Centers. They had been by-passing them and establishing direct links between Central and the reservations, links that meant power was being siphoned out of the Area Offices toward the reservation, and, by implication, back toward Central as well. According to Alexander McNabb, director of operating services, from April 1970 to May of the following year, they had tried to pump from $\$ 10$ to $\$ 15$ million directly into reservation economies. Moreover, he had rewritten Bureau contracting procedures to conform with Insurgent ideals. But on June $28 \mathrm{McNabb}$ was divested of contracting authority in the wake of a Government Accounting Of-

9. Gaillard, Indians Demand Bureau Reform, 2 Race Relations Rep. no. 18, at 6. 9 (1971). 
fice audit of the contracting activities which concluded that the Bureau did not have any legislative mandate to justify either the new procedures or a number of the contracts. In the four months following McNabb's removal, not one new contract was negotiated out of the 119 that were pending in June, but 93 old contracts were renegotiated. ${ }^{10}$

One month later the counterattack produced its most substantial victory. On July 26 Secretary Morton revived the office of Deputy Commissioner and filled it with John O. Crow, who had held the same post under Phileo Nash and who had the reputation of being a tough, but progressive Haskell Mafia Old Liner. Crow was an advocate of self-determination, who respected the drives and talents of the Insurgents, but who also realized that none of them had the years of Bureau experience that create an intuitive understanding and appreciation for the unique amenities and attributes of the federal way of life: in-house statemanship, personal obscurity and loyalty to bureauacratic efficiency. It was to be Crow's task to give the Central Office at least the appearance of a standard bureaucracy and, because the Old Liners were already beginning to subvert and stall, to turn Insurgent expectations and deeds into programs compatible with the Old Liners' world view.

For this Crow was given powers equal to Bruce's in administrative areas-i.e., the ability to direct Central Office manpower-which he first used to demote Leon Cook, the most vocal and impatient of the Insurgents, from Acting Director of Economic Development to Deputy Director under a nonIndian Old Liner, William Freeman. Crow then removed Ernest Stevens from the job of Acting Associate Commissioner for Education and Programs (one of the top four jobs in the Bureau), returned him to Director of Community Services, and suggested abolishing the Education and Program Office. Then he ordered William Veeder transferred to Phoenix at the request of John Artichoker, the Area Director there, and ordered Phillip Corke transferred to a subsidiary Bureau position in Denver.

To Indians, who were already complaining about the attempts to dismantle Bruce's Bureau reforms, the Veeder transfer was the precipitating event. On September 21 a delegation of tribal chairmen voiced their disapproval to White House and Interior officials at a meeting in the Interior Building at the same time that members of the American Indian Movement and the National Indian Youth Council were marching on the Bureau headquarters in Washington in an unsuccessful attempt to make a citizen's arrest of John $O$. Crow. This combination of militant and middle-of-the-road protest did have an impact. The Veeder and Corke transfers were rescinded and it became obvious to everyone that another attempt would have to be made to remodel the Central Office to make it big enough for Crow and his allies and for Bruce and his allies.

10. Id. 
The new reorganization which Bruce sent to Morton in October included the appointment of Ernest Stevens as permanent Associate Commissioner for Education and Programs and the elevation of that office to the third highest rank in the Bureau. It also called for the abolition of the Associate Commissioner for Support Services in order to enhance McNabb's position. As a compromise, Leon Cook would not be affected by the restructuring. However, Cook soon resigned and was elected president of the National Congress of American Indians where he cemented an alliance between that organization and the surviving Insurgents.

Bruce's plan, which he admitted was a compromise, was further modified by Victor, Rogers, and Morton. By the time it was announced in December it bore only slight resemblance to Bruce's original proposal, but it did contain a little of something for everyone. It abolished all associate commissioner positions and replaced them with thirteen division offices, three of which were headed by Stevens, McNabb, and their non-Indian ally Robert Gajdys. The rest were a mixture of New Teamers and Crow supporters. However, Crow's authority was expanded across the board to the point where he became Bruce's equal in everything but name. It was an unwieldy structure from a management point of view, but it was not a management-made structure-it was a political one. And while it made for a broad, symmetrical flow chart, it also created an unplotted picture of power that Gaillard described as the "multiple-sandwich, squeeze-play effect."

At the top of the stack was Secretary Morton, a neutral, who could be responsive to either side. Below Morton was Interior Under-secretary for Public Land Management, Harrison Loesch, who was no friend of Bruce or the Insurgents. But for approval of Bureau policy or programs, it was Loesch through whom Bruce worked, Bruce through whom Crow worked, Crow through whom the Insurgents worked, and the Insurgents through whom the Old Liners and Hard Hats. worked. And at the base of the stack were the reservation Indians whose expectations of the Bureau had been raised by the Insurgency and who were putting more pressure on the Old Liners and Hard Hats than those two factions had ever felt from below. No one rested easy for the next eleven months and it was not the Bureau's most productive time. Everyone was trying to engineer a new offensive.

But the final initiative did not belong to either side. It was commandeered by the Trail of Broken Treaties Caravan and its six-day occupation of the Central Office. ${ }^{11}$ When the Caravan left, it was clear that the Bureau would never be the same. During the weeks of Central Office renovation that followed the occupation, the staff was dispersed into any federal space available, communications faltered, and the work load piled high. The confusion was a propaganda coup for the Hard Hats who sought permanently to discredit

11. See generally V. Deloria, Jr., Behind the Trail of Broken Treaties (1974). 
Bruce and the Insurgents by charging that they were accessories to the takeover. Authority over the Central Office fell to the receivers; partly to Morton, but mainly to Loesch, who appointed Crow to rebuild the structure. Crow, however, was unable to make any headway. The takeover had so polarized the factions and crystallized the squeeze-play that any action was impossible. Early in December, Morton gave Crow and Bruce six weeks notice, relieved them of all authority in the Bureau and transferred the Bureau out from under Loesch's authority. Most of the more notable combatants were swept from the Central Office. Some of the New Team stayed, as did some of the Old Liners. Crow, Bruce, and Stevens left government service and $\mathrm{McNabb}$ and Gajdys moved into the Interior Office of Management and Budget.

On December 6, 1972 Morton put the Bureau under the temporary command of Richard Bodman, Assistant Interior Secretary for Management and Budget, who was to oversee the revival of day-to-day operations and develop the next final solution for the Central Office's structural dilemma. Six weeks later Bodman announced his plan to streamline the Bureau's operations by reducing the number of Central Office divisions from thirteen to seven and the number of Central Office positions from 1,375 to 715 . It was obvious that Secretary Morton was taking control of Indian Affairs and was using Bodman, the management technician, to de-politicize the Bureau and make it conform to Interior's expectations. But Morton had not counted on the strength remaining in the factions, or the influence McNabb and Gajdys would have with Bodman and his successors in the Office of Management and Budget, or the influence the Hard Hat-Old Line axis would have with Marvin Franklin, whom Morton appointed, on February 7, 1973, as Assistant Secretary for Indian Affairs with duties as acting Commissioner.

Franklin made two notable changes in Bodman's reorganization plan. First, he reduced the number of Central divisions from seven to six. The heads of each division were, together with the Commissioner, to act as the Bureau's governing board. The Commissioner was to preside over meetings but, like the other members, had only one vote in policy decisions. Second, Franklin created, as an adjunct to the Commissioner's office, a new advisory panel, the Committee on Field and Internal Operations. It soon became apparent that through this new structure Franklin was once again placing the Bureau's reliance on the expert's experts, the conservative and politically astute Hard Hats.

Franklin appointed as acting heads of the six divisions leading Old Liners, most of whom had been detailed into the Central Office from permanent assignments as Assistant Area Directors. Next he filled the Committee on Field and Internal Operations with a majority of Area Directors, including the leading Hard Hats. In theory the Committee was merely an advisory board whose sole responsibility was to meet monthly with Franklin for consultation 
on policy matters. But under Franklin, as so often in the past, governing boards may not do all of the governing and the advisory board may do more than merely advise.

The actual structure became somewhat clearer on April 10 when Franklin issued his major organizational memo. Part of it was commonplace, like the admonition that "the control of power is the control of money and manpower." 12 The memo then explained that bureaucratic control would follow the line set out in the new organizational chart: from Commissioner and Deputy Commissioner to Area Directors to Agency Superintendents. However, such a plan is only as plausible as the flow chart is dependable. And Franklin weakened the dependability of the flow chart by doubling back and writing: "The management concepts that are required represent changes in the roles of the Central Office staff. Those offices must carry out policy established by line authority." ${ }^{3}$ But since the key members of the Central Office staff-the six acting division heads-were on leave from positions as Assistant Area Directors-and still consulted monthly with their superiors in the field-the governing board members effectively remained subordinates of the Hard Hat Area Directors. Formally and informally it made for some strange structural geometry, a circuitous and discreet way for the Area Directors, through intermediaries and superiors, to tell themselves and the Bureau what to do.

If the structure had been allowed to stand it would have been a total Hard Hat victory, but it would not have been a total return to a pre-Bruce Bureau. The Bruce Administration was the soundest evidence yet that undeniable change had occurred in Indian Country and Congress. It was obvious that the concept of self-determination, though frustrated by the war in Central, was a policy taken for granted on most reservations. It would soon be given legislative effect in the Indian Self-Determination and Education Assistance Act. ${ }^{14}$ But who would turn the relatively few pages of the Self-Determination and Education Act into regulations, and who would revise the BIA manuals to reflect the law? What remained of Insurgent strength foresaw the possibility that under Franklin those jobs would fall to the Old Liners who would act on the advice and consent of the Hard Hats. The Insurgents were fearful that such an axis could regulate self-determination to its own advantage in the same way that that axis had accused the Insurgents of using selfdetermination to their own advantage, and, more to the point, in the same way that the axis had subverted Collier's concept by transforming Area Offices from intermediate service centers into inscrutable and powerful miniature Central Offices.

12. National Congress of American Indians, Synopsis of the National Consultation on BIA Delivery Systems, Denver, Sept. 14-15, 1973 (unpublished manuscript on file with the author).

13. Id.

14. 25 U.S.C. $\$ 450$ (Supp. 1976). 
But the structure was not allowed to stand, for it soon encountered opposition from two fronts. Publicly, Franklin's realignment was attacked during the summer of 1973 by the National Congress of American Indians and its closest congressional ally, Senator James Abourezk, who requested that Morton once again take charge of the Bureau. Franklin, they charged, was acting "illegally" because he had gone without Senate confirmation longer than the law allowed. At the same time, but behind the scenes, Franklin was also drawing fire from another study group created by Interior Secretary Morton called the Committee on Bureau Reorganization. This committee included Franklin, Interior Solicitor Kent Frizzell, Assistant Interior Secretary for Program Development Larry Lynn, and Assistant Interior Secretary for Management James Clark. The majority of these men wanted Franklin to stop the realignment for the ostensible reason that its field research group had not completed a report on how reservation Indians thought the Bureau should be structured. That was probably only part of their reason; when the report appeared late that fall stating that Indians wanted a Bruce-like structure, the entire matter was quietly swept under the rug. A more plausible reason for the committee's opposition was that it reflected the attitude of the Interior Department, which had expected Franklin to further the Department's own Bureau reorganization plan. Franklin, however, had listened more to the Area Directors than he had to Interior. In August, Franklin announced that he was stopping the implementation of his realignment and was withdrawing his name from consideration as Commissioner. In his written announcement to Interior Undersecretary John Whittaker, Franklin broadly implied that he had been undercut by the Administration.

Interior's plan for the Bureau was never articulated publicly, but in July 1973 , an issue arose that gave the plan some definition besides adding spice and confusion to the summer's hostilities. During that month John Sidle, Deputy Assistant Secretary for Program Development, authored an "administratively confidential" memo to Undersecretary Whittaker, who was then the intermediary between Secretary Morton and the Bureau. The memo began: "During our conversation of June 15 you [Whittaker] questioned the need for and desirability of having BIA Area Directors." 15 Sidle then agreed that the question had merit and posed two alternatives to the structure: replace the directors with "new, young management" or "reorganize the Area Offices out of existence" and place their duties in Federal Regional Councils.

Sidle went on to argue against replacement on the grounds that Bruce's rotation policy had failed to shake the power of the Area Directors and cited, for additional proof, instances in which Oklahoma Representative Carl Albert and Montana Senators Metcalf and Mansfield had intervened to prevent the

15. American Indian Press Ass'n News Dispatch, Oct. 2, 1973, in which the Sidle Memo was printed in full. 
transfer of Area Directors out of their respective states. The best option in Sidle's opinion was the abolition of the Area Offices. In this regard the memo had been heavily influenced by two of Sidle's subordinates, Insurgents McNabb and Gajdys. Sidle even reminded Whittaker that McNabb had once briefed him on the "effectiveness of the various Area Directors."

Sidle concluded with the belief that Whittaker and others in Interior could probably gather support from the National Congress of American Indians (NCAI) and the National Indian Youth Council for his "regionalization" plan. But here he was in error because he had not counted on the total distrust some Insurgents, including those closely associated with NCAI, had for Nixon's New Federalism Doctrine, of which the Federal Regional Councils were a part. They felt that any dispersal of power out of the BIA would only cripple the Bureau's integrity, and thus the integrity of the unique Indianfederal government relationship that lies at the heart of all attempts toward self-determination, sovereignty, and trust protection. NCAI lobbied this point with Franklin's Old Line division heads, who agreed. Sidle was also unaware that after leaving the Bureau the Insurgents were slightly divided over the question of Bureau integrity. One side, those who opposed Sidle, wanted all Bureau power put back into the Central Office in the hope that someday the Bureau could be transformed into a Super Bureau, an independent public corporation that could provide services to reservations and be governed by the people it served. But the other side, those who backed Sidle, wanted a gradual dispersal of Bureau service programs into those agencies of the government established specifically for service: Indian Education would follow Indian Health into HEW, Indian Housing would move into HUD, and manpower development would move into the Labor Department. In other words, the plan was to kill the Bureau through gradual evisceration. This, of course, would be contingent on the creation of the Indian Trust Council Authority, a legislative proposal that seeks to establish an independent legal commission which would protect tribal governmental sovereignty and the trust status. ${ }^{16}$

Regionalization, then, created a new and somewhat bewildering line-up of allies. The anti-regionalists were the Old Line-Hard Hat Axis and one faction of the Insurgency. The regionalists were the other side of the Insurgency and the top officials of the Interior Department. Each had its share of grass roots support. And each, except the Old Line-Hard Hat Axis, was opposed to Franklin on the issue of realignment. However, on the issue of regionalization, Franklin seemed to be in everybody's camp. Although he had championed the Area Director's return to power, Franklin stated in an interview in November 1973 that placing the functions of the Area Offices in Federal Regional Councils was a logical extension of the realignment policy. ${ }^{17}$

16. S. 1339, 93d Cong., 2d Sess. (1973).

17. Nickeson, Paternalism and lis Mates, 5 Race Relations Rep. no. 5, at 22 (1974). 
The hostilities suddenly ceased in December 1973 when Morris Thompson was confirmed as Indian Commissioner. There were several reasons for this cessation, but only two were apparent at the time. First, commissioners, like presidents, are given a honeymoon period with the Bureau while their staffs are selected and their intentions become clear. Thompson's honeymoon was a long one because his staff selection seemed interminable, and as his people began to fall into place no definite Central Office characteristic developed as it had in the two previous administrations. Secondly, Thompson opened the doors of the Central Office to everyone who had complained that either Bruce or Franklin had excluded them. Both of these factors had a cooling effect.

Only later did it become clear that during these initial months the present organization of the Bureau was taking shape almost unnoticed. Currently, the visible structure under Thompson is a modified version of Franklin's modifications of the Bodman plan. The only major changes have been the abolition of the Committee on Field and Internal Operations, and the removal of the Office of Public Affairs, one of the six divisions under Franklin, from what could be called the Program Line and its incorporation into the Commissioner's own staff. But more significantly, Thompson's Central Office is largely a de-politicized one, a fact that pleases Interior, which in the past two years has made inroads into policy making, primarily through the Interior Solicitor's office. There is now in Central a sprinkling of Old Liners, an Insurgency flavor here and there, and a couple of small power domains that appear to be personal and free of the partisanship that so characterized the two previous administrations. But there are no visible Hard Hats. They and their closest Old Line associates have left the Central Office and have once again entrenched themselves in the Area Offices. Although the power to decide policy formally resides in the Central Office, the actual administration of programs is largely in the hands of the Area Directors. Powers delegated by the Secretary to the Commissioner have effectively been redelegated to the Area Directors and their subordinates. The process merely institutionalizes what has existed since Franklin's organizational memo. The Area Offices have been given the responsibility of administration and control of almost all Bureau programs. Through their control of money and manpower they maintain substantial control of policy, for it would be impossible for the Central Office to ignore or slight in the least the stated expectations of those who are administering the programs for which Central is establishing policy. However, there are indications that the Area Offices have never regained their old prominance, but were also weakened during the five year war. The composite losses of the opposition were never translated directly into Area Office gains; the war had a degenerating effect on all of its participants. For example, several of the Area Offices have gone without permanent directors for months, a situation that resulted in a suit being filed recently against the Department of 
Interior by tribes in the Albuquerque area. ${ }^{18}$ In another instance, some Dakota tribes petitioned for the closure of the Aberdeen Area Office late in 1974, and Central appeared willing to follow those wishes had there been unanimity among the tribes in the area. There also have been a number of management complaints that the Area Offices have become little more than duplicate and expensive bottlenecks in the day-to-day processing of Bureau work. For this reason the Area Offices have been required to bear an unequal share in Interior's efforts to reduce its overall work force. In other words, the Area Offices and their power are no longer being taken for granted, the worst setback a sub-institution of the self-made type can suffer.

When taken as a whole, the greatest accomplishment of the entire structural war was an acceleration of entropy. When the war began all the energies were directed toward reforming the relationships between the Bureau and its constituency. But it soon became apparent that such reform was totally contingent upon a reformation within the structural sphere of the Bureau. Yet when pulled into this sphere, where the constituency is secondary, the action suddenly became almost a conflict over structure for its own sake, fought as if structure had far more causal capabilities than it can claim in reality. From this point there was no other way for the war to go except toward a degrading of energies from a concrete level to increasingly abstract ones. The final realignment/regionalization controversy was little more than a decadent parody of the action that touched off the war. The chronology of the war indicates that the deeper the action went into structure the closer it came to a dead end, because structure is an end. Structure is the cause of little, but the effect of much: It is a temporary manifestation of the interplay between policy and power. In the long run it will make little difference whether the Bureau takes on the form of Amtrac and the TVA, or dissolves into the total federal network. If the elements of policy and power remain unchanged, the Bureau will still be the Bureau (or Bureaus, as the case might be). Such has always been the case. Despite the six structural changes that the Bureau has undergone in the past six years-despite all past changes-the Bureau has remained essentially unchanged since 1824 , because Indian policy and the powers that implement it have changed only in their complexity since John Cabot put Britain's Christian claim on North America in 1497.

As the Indian Policy Review Commission reexamines the formal organization of the Bureau, it might best look at it for what it is-a costume of changeable style in which the Bureau chooses to dress to go to work. Obviously, it is not enough to consider style; the effort must be placed on the substance behind it. In this light it might be best for the recommendations concerning the structure of the BIA to be the last that unfold from the Commission as it works out its own style for countering that of the status quo.

18. Pueblo of Acoma v. Hathaway, Civil No. 75-419 (D.N.M., filed July 16, 1975). 